\title{
Candida albicans morphologies revealed by scanning electron microscopy analysis
}

\author{
M. Staniszewska ${ }^{1}$, M.Bondaryk ${ }^{1}$, E. Swoboda-Kopec ${ }^{2}$, K. Siennicka ${ }^{3}$, G. Sygitowicz ${ }^{4}$, \\ W. Kurzatkowski ${ }^{1}$ \\ ${ }^{1}$ National Institute of Public Health, National Institute of Hygiene, \\ Independent Laboratory of Streptomyces and Fungi Imperfecti, Warsaw, Poland. \\ ${ }^{2}$ Department of Microbiology, Medical University of Warsaw, Poland. \\ ${ }^{3}$ Warsaw University of Life Sciences, Poland. \\ ${ }^{4}$ Department of Biochemistry and Clinical Chemistry, Medical University of Warsaw, Poland.
}

Submitted: February 1, 2012; Approved: September 10, 2012.

\begin{abstract}
Scanning electron microscope (SEM) observations were used to analyze particular morphologies of Candida albicans clinical isolate (strain 82) and mutants defective in hyphae-promoting genes $E F G 1$ (strain HLC52) and/ or CPH1 (strains HLC54 and Can16). Transcription factors Efg1 and Cph1 play role in regulating filamentation and adhesion of $C$. albicans' morphologies. Comparative analysis of such mutants and clinical isolate showed that Efg1 is required for human serum-induced cell growth and morphological switching. In the study, distinct differences between ultrastructural patterns of clinical strain's and null mutants' morphologies were observed (spherical vs tube-like blastoconidia, or solid and fragile constricted septa $v s$ only the latter observed in strains with $E F G 1$ deleted). In addition, wild type strain displayed smooth colonies of cells in comparison to mutants which exhibited wrinkled phenotype. It was observed that blastoconidia of clinical strain exhibited either polarly or randomly located budding. Contrariwise, morphotypes of mutants showed either multiple polar budding or a centrally located single bud scar (mother-daughter cell junction) distinguishing tube-like yeast/ pseudohyphal growth (the length-to-width ratios larger than 1.5). In their planktonic form of growth, blastoconidia of clinical bloodstream isolate formed constitutively true hyphae under undiluted human serum inducing conditions. It was found that true hyphae are essential elements for developing structural integrity of conglomerate, as mutants displaying defects in their flocculation and conglomerate-forming abilities in serum. While filamentation is an important virulence trait in $C$. albicans the true hyphae are the morphologies which may be expected to play a role in bloodstream infections.
\end{abstract}

Key words: Candida albicans, pleomorphism, ultrastructure, virulence.

\section{Introduction}

Literature data described that individual pleomorphic forms of Candida albicans provide critical functions required for the pathogenic lifestyle (Cullen and Sprague, 2000; Yang et al., 2009; Chung et al., 2010; Ness et al., 2010; Noble et al., 2010). Although the distinguishing criteria between various morphotypes are still a matter of debate, some of them have been established based upon transmission electron microscopy (TEM) by Müller and
Melchinger (2006). Our previous studies (Staniszewska 2009; Staniszewska et al., 2011, 2012) based upon phasecontrast microscope as well as transmission and scanning electron microscopes partially provided criteria of $C$. albicans wild type morphotypes i.e.: criteria of breakable septa typical for blastoconidia and pseudohyphae, features of massive septa characterizing true hyphae, privileged areas of budding or branching, relations between the cultivation conditions and growth of particular pleomorphic forms, fibrous appearance at the outer surface of the cell

Send correspondence to M. Staniszewska. Independent Laboratory of Streptomyces and Fungi Imperfecti, National Institute of Public Health, National Institute of Hygiene, 24 Chocimska, 00-791 Warsaw, Poland. E-mail: mstaniszewska@pzh.gov.pl. 
wall of different morphotypes, cellular and hyphal organization of mycelium-like aggregates. Under in vitro conditions, the interconversion among the cell types are induced by modifying the $\mathrm{pH}$, temperature, and/ or serum concentration in the growth medium (Barnett 2008; Kruppa 2009; Staniszewska 2009; Noble et al., 2010; Staniszewska et al., 2011, 2012). Moreover, the success of $C$. albicans as a pathogen is related in part to polymorphism as strains blocked in morphogenesis proved to be non-virulent (Lo et al., 1997; Kumamoto and Vinces, 2005; Yang et al., 2009). While hyphal forms are found in many patients suffering from candidiasis and are thought to be necessary for infection and virulence (Sudbery et al., 2004) we expected that true hyphae may be important for increased capacity of blood infections. The morphotypes are currently under intensive investigation and may serve as model forms for the elucidation of the role of $C$. albicans in virulence. To our knowledge, $C$. albicans is the major cause of serious fungal infections in the United States, and Candida species are the fourth most commonly cultured microbes from blood (Noble et al., 2010). Thus, in the study we included undiluted blood serum to mimic environmental cues found within different niches of the host. The primary objectives of the study were the following: (i) to provide the morphology patterns of particular pleomorphic forms of C. albicans clinical bloodstream isolate (strain 82) based on scanning electron microscopic (SEM) analysis, (ii) and to compare the cellular ultrastructure of clinical strain 82 and mutants with hyphae-promoting genes EFG1 (strain HLC52) and/ or CPH1 (HLC54 and Can16) defects under undiluted human serum influence at human body temperature. Additionally, the role of EFG1 and CPH1 in cell growth and morphological switching can be estimated by comparing the mutants and clinical isolate under human serum influence in vitro.

\section{Material and Methods}

\section{Candida albicans strains and culture conditions}

All of the strains used in the study are listed in Table 1.

The Candida albicans clinical strain (named strain 82) was isolated from blood culture of patient hospitalized in the Children's Memorial Health Institute (Department of Oncology). Prior to the performed studies, strain 82 and mutant strains (Can16, HLC52 and HLC54) were routinely cultured on Sabouraud dextrose agar at $30{ }^{\circ} \mathrm{C}$ for $18 \mathrm{~h}$ (Staniszewska et al., 2011), then a loopful $(10 \mu \mathrm{L})$ of cultures was reinoculated into $10 \mathrm{~mL}$ of YEPD medium (Ness et al., 2010) and incubated at $30{ }^{\circ} \mathrm{C}$ for $18 \mathrm{~h}$. The strains were stored on Microbank cryovial beads (Prolab Diagnostics, Canada) at $-70{ }^{\circ} \mathrm{C}$.

Induction of germ tubes, pseudohyphae and true hyphae in undiluted human serum. The human serum was obtained from healthy human volunteers (Department of Biochemistry of the Institute of Haematology and Transfusion Medicine in Warsaw). The serum was filtered using Millex filter with $0.45 \mu \mathrm{m}$ durapore membrane (Millipore, Carrigtwohill, Ireland). For the next culture of the each strain, $50 \mu \mathrm{L}$ of the blastoconidial suspension $\left(1.5-5 \times 10^{7}\right.$ cfu $\mathrm{mL}^{-1}$ ) grown in YEPD medium was transferred to Eppendorf vial containing filtered undiluted human serum (500 $\mu \mathrm{L}, \mathrm{pH} 7.1-7.4)$. To examine the wild type strain's morphologies, blastoconidia were grown at $37{ }^{\circ} \mathrm{C}$ for the following time periods: 1, 2, 6, 18 and $48 \mathrm{~h}$. For the each mutant's forms, blastoconidia were incubated at $37^{\circ} \mathrm{C}$ for $18 \mathrm{~h}$.

Table 1 - Candida albicans strains used in the current study.

\begin{tabular}{|c|c|c|c|}
\hline Strain & Genotype & $\begin{array}{l}\text { Phenotype under undiluted human serum } \\
\text { influence }\end{array}$ & References \\
\hline 82 & Wild type/ clinical bloodstream isolate & $\begin{array}{l}\text { Spherical blastoconidia with polarly or ran- } \\
\text { domly located budding; true hyphae forma- } \\
\text { tion }\end{array}$ & Staniszewska et al., 2011 \\
\hline Can16 & $\begin{array}{l}\text { ura3::1 1imm434/ura3::1 1imm434 } \\
\text { cph1::hisG/cph1::hisG-URA3-hisG }\end{array}$ & $\begin{array}{l}\text { Extended tube-like blastoconidia with mul- } \\
\text { tiple or singular bud scars at the poles, true } \\
\text { hyphae formation }\end{array}$ & Lo et al., 1997 \\
\hline HLC52 & $\begin{array}{l}\text { ura3::1imm434/ura3::1imm } 434 \\
\text { efg1 }:: \text { hisG/efg1 }:: \text { hisG-URA3-hisG }\end{array}$ & $\begin{array}{l}\text { Constitutive growth of elongated tube- } \\
\text { shaped buds with single scar at the tips } \\
\text { (pseudohyphae) }\end{array}$ & Lo et al., 1997 \\
\hline HLC54 & $\begin{array}{l}\text { ura3::1imm434/ura3::1imm } 434 \\
\text { cph1::hisG/cph1::hisG } \\
\text { efg1::hisG/efg1 }: \because \text { hisG-URA3-hisG }\end{array}$ & & \multirow{3}{*}{ Schild et al., 2011} \\
\hline$\Delta \operatorname{sap} 9[\mathrm{pClp} 10]$ & 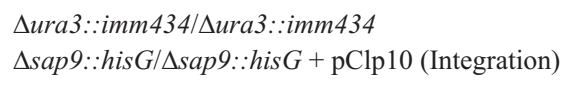 & \multirow{2}{*}{$\begin{array}{l}\text { Spherical blastoconidia with polarly and } \\
\text { laterally located scars, true hyphae forma- } \\
\text { tion }\end{array}$} & \\
\hline$\Delta$ sap $9 / \Delta \operatorname{sap} 10[\mathrm{pClp} 10]$ & 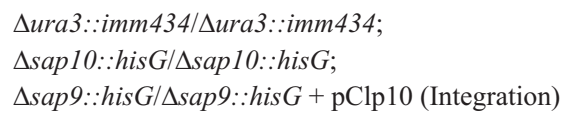 & & \\
\hline
\end{tabular}




\section{Microscopy study}

To examine cell morphology, samples were prepared as described previously Oliviera et al. (2010). Briefly, morphotypes of the each strain were fixated with $2.5 \%$ glutaraldehyde in $0.1 \mathrm{M}$ phosphate buffer ( $\mathrm{pH} \mathrm{7.2)}$ for $18 \mathrm{~h}$ at a low temperature $\left(5-6^{\circ} \mathrm{C}\right)$. Then, the samples were carefully washed with $0.1 \mathrm{M}$ phosphate buffer ( $\mathrm{pH}$ 7.2). Postfixation was carried out for $2 \mathrm{~h}$ at room temperature with $2 \%$ osmium tetroxide. Initial dehydration was accomplished by placing specimens in the following series of ethanol gradients: $50 \%$ and $70 \%$ (two times for $10 \mathrm{~min}$ ), $95 \%$ (two times for $5 \mathrm{~min}$ ) and 100\% (two times for $1 \mathrm{~min}$ ), respectively. Then, samples were dehydrated with acetone (two times for $30 \mathrm{~s}$ ) until dried by the critical point method in liquid $\mathrm{CO}_{2}$. Subsequently, the specimens of the wild type strain were coated with gold in a vacuum evaporator and examined with a scanning electron microscope (SEM Quanta-200, FEI, Czech Republic). In the case of the mutant strains, after post-fixation morphotypes were dehydrated two times for $10 \mathrm{~min}$ with graded ethanol $(50 \%$ and $75 \%$ ) followed by dehydration with acetone (two times for $30 \mathrm{~s})$. The dried specimens were coated with osmium tetroxide and observation was done under scanning electron microscope Hitachi S-5500 (Japan). Images were assembled with Photoshop (Adobe Photoshop CS3 Extended). Cell di- mensions were determined by using bars. Morphology index (Mi).

The morphology index (Mi) described by MersonDavies and Odds (1989) was applied in this study to depict each of the particular pleomorphic forms of the clinical bloodstream isolate. The morphology index was determined for the each cell type based on the formula: $\mathrm{Mi}=l s / d^{2}$. The length of the cell (1), maximum diameter of the cell (d) and diameter at the septal junction (s) were determined for 456 randomly selected cells of the clinical strain 82 .

Statistical analysis of the clinical strain's pleomorphic forms. The morphology index (Mi) of the different pleomorphic forms was analyzed by descriptive statistics (number of cells measured, average, SD, minimum and maximum). Analysis was done using SPSS 12.0/ (//SPSS for Windows, Rel 12.0.1, 2004, Chicago: SPSS INC/).

\section{Results}

\section{Blastoconidia}

Under undiluted human serum blastoconidia of the clinical bloodstream isolate appeared as ovoid, spherical cells (Figure 1A). On the contrary, the colony morphology of the mutants' blastoconidia looked as significantly ex-
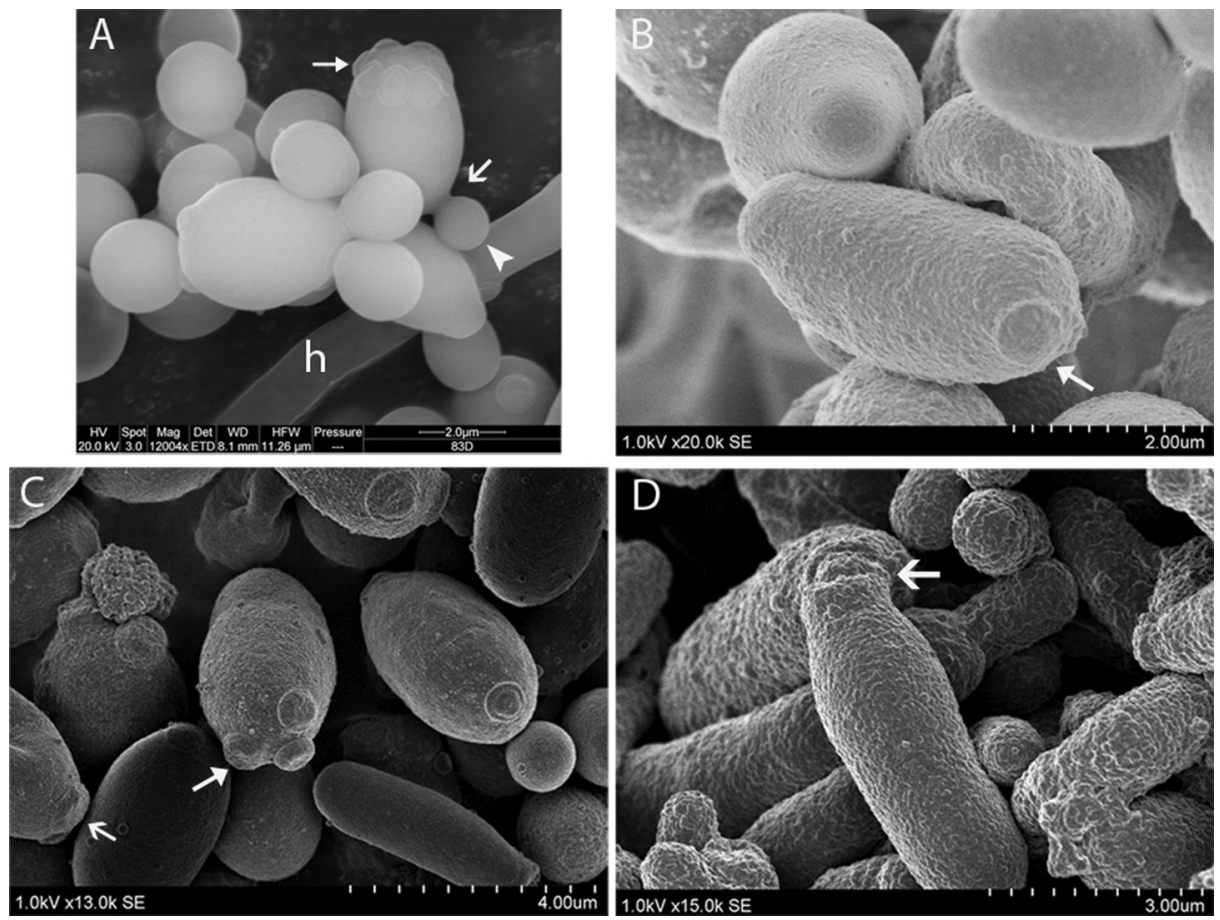

Figure 1 - A single-celled and budding yeast forms (blastospores). (A) The Candida albicans strain 82 incubated at $30{ }^{\circ} \mathrm{C}$ for $48 \mathrm{~h}$ in undiluted human serum. Note the ring of scars (arrows) located at one pole (tip) of the blastoconidial cell and a bud emerging from the opposite tip of the cell (arrowhead). Fragile blastoconidial septum is seen (open arrow). Note true hyphal filament (h). (B-D) Mutants of morphogenesis upon undiluted serum stimulation for $18 \mathrm{~h}$ at $37^{\circ} \mathrm{C}$ are visualized. (B) The homozygous efg $1 \Delta / \mathrm{efg} 1 \Delta$ mutant (strain HLC52) develops elongated blastoconidia with several scars located at the cell pole (arrow). (C) The homozygous $c p h 1 \Delta / \operatorname{cph} 1 \Delta$ mutant (strain Can16) forms tube-like cells either with multiple (arrow) or singular (open arrow) bud scars located at the poles. (D) The double morphogenesis mutant efg $1 \Delta /$ efg $1 \Delta c p h 1 \Delta / c p h 1 \Delta$ (strain HLC 54) forms elongated blastoconidial cells. Note the single truncated bud scar at the tips of the tube-like cells (open arrow). Scanning electron micrographs. 
tended tube-like forms (Figure 1B-D). The average length-to-width ratios for the mutants' cells $(\mathrm{n}=138)$ were larger than 1.5. In this regard, the presented results suggested that a large number of cells testified pseudohyphae, not blastoconidia.

In the case of the mutants, the ratio of length to width was measured to reveal their defects in cell morphology and to clearly distinguish pseudohyphal cells from yeast-form cells ( $\mathrm{n}>50$ for each strain). Blastoconidial cell poles were observed to be the privileged budding areas (Figure 1A, C). Generally, several polarly located scars were noted at the tips of the strains tested as in Figure 1A-C.

To examine the ultrastructural organization of scars at the surface of blastoconidia following undiluted serum induction, we included the $\operatorname{sap} 9 \Delta / \operatorname{sap} 9 \Delta$ and $\operatorname{sap} 9 \Delta / \operatorname{sap} 9 \Delta$ sap 10 $/$ sap $10 \Delta$ mutants in this analysis. Sap9 and Sap10 are cell surface-associated aspartic proteases. In contrast to the above, SEM analysis revealed bud scars located randomly on the yeast cells surface of the $\operatorname{sap} 9 \Delta / \operatorname{sap} 9 \Delta$ and sap $9 \Delta / \operatorname{sap} 9 \Delta \operatorname{sap} 10 \Delta /$ sap $10 \Delta$ mutants as well as the wild type strain 82 (Figure 2B-D).

As can be observed in Figure 3D, the wild type strain showed a smooth and homogenous cell surface, whereas the mutants with morphology defects such as efg $1 \Delta /$ efg $1 \Delta$ (strain HLC52; Figure 3A), cph1 $\Delta / c p h 1 \Delta$ (strain Can16; Figure 3B), $c p h 1 \Delta / c p h 1 \Delta$ efg $1 \Delta /$ efg $1 \Delta$ (strain HLC54; Fig- ure $3 \mathrm{C}$ ) showed a highly heterogeneous, warty and rougher cell surface.

\section{Germ tubes and true hyphae}

SEM analysis of the wild type strain 82 revealed that morphotypes appear as clustered cells of filamentous morphology embedded in a flocculent extracellular material (Figure 4B, D). Fibrillar material was observed as connecting neighbouring morphologies.

SEM showed that long true hyphal forms with rings of truncated bud scars located at one (Figure $5 \mathrm{~A}$ ) or at both sides of the solid septum were observed (Figure 5B).

True hyphal forms exhibited homogenously elongated shape and lack of constrictions at the solid septum. The average length-to-width ratios for the clinical strain's true hyphal cells $(n=215)$ were about 6.91 (Table 2). After $48 \mathrm{~h}$ of incubation in undiluted human serum buds emerging from the hyphal forms were noted (Figure 5A).

Altered morphogenesis of all the mutant strains was observed (Figure 6A-D). From all the mutants used in the study only the $\operatorname{cph} 1 \Delta / \operatorname{cph} 1 \Delta$ was able to undergo morphological transition and form true hyphae (Figure 6A). The latter strain formed hyphae (retaining solid septum) in hypha-inducing human serum, although the hyphal length observed was much shorter than that seen in the wild type cells (Figure 4B-D). The relative percentage of mycelia forms was lower in the case of $c p h 1 \Delta / c p h 1 \Delta$ (Figure 6A)
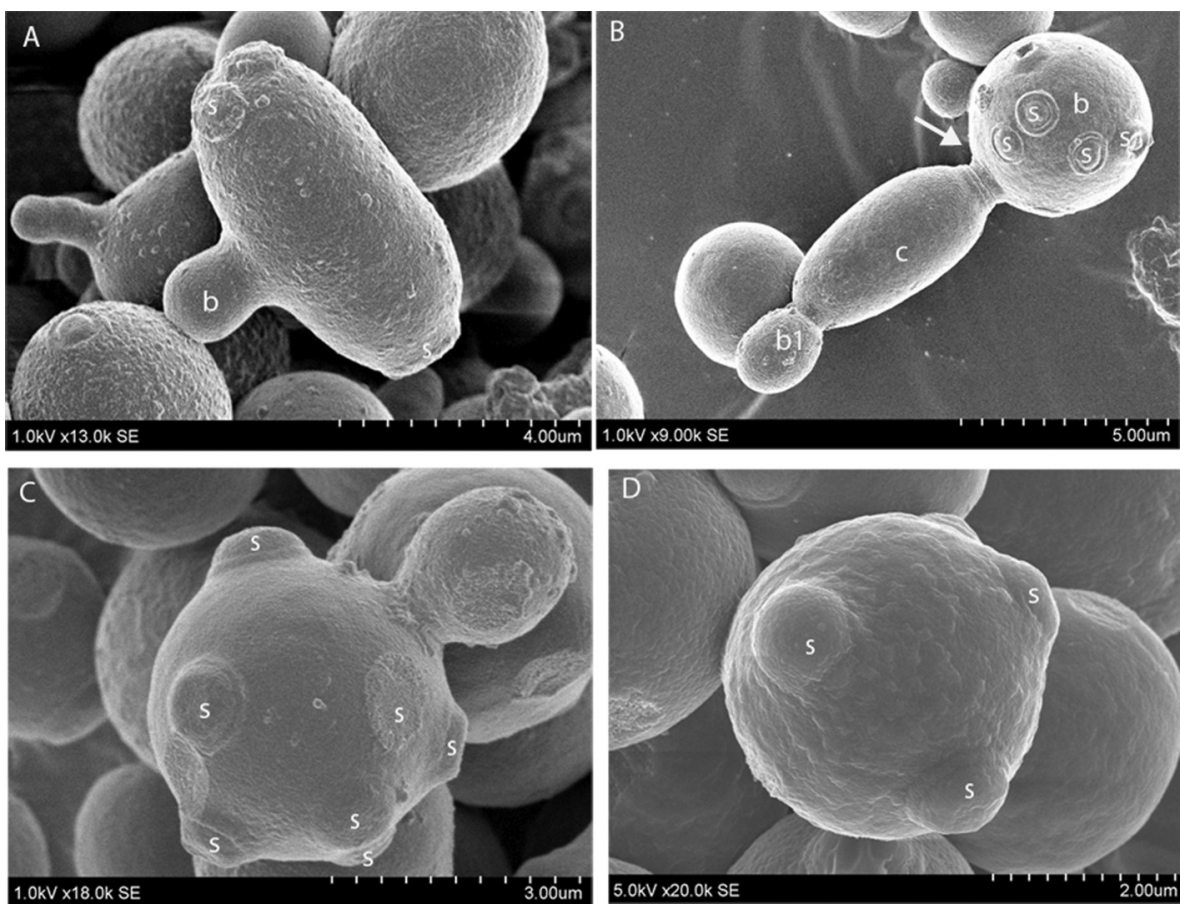

Figure 2 - Scars ultrastructure observed by SEM. (A, B) Surface of 18-hours-old colonies of C. albicans under hypha-inducing conditions (e.g., undiluted human serum). (A) Blastoconidial cells morphology and cellular budding typical for the strain $\Delta$ sap9-10. Note bipolarlly located scars (s) and laterally located new bud (b). (B) The $\Delta s a p 9$ mutant. Fine details of pseudohypha are discerned. Oval blastoconidial mother cell (b) with fragile septa (arrow) is seen. Scars (s) localized randomly were observed. Note elongated pseudohypha (c) and the new budding yeast cell (b1) on the pole. (C, D) The clinical strain 82 shows budding phenotype after $18 \mathrm{~h}$ incubation at $30^{\circ} \mathrm{C}$ in YEPD medium. Note the randomly located scars (s). 

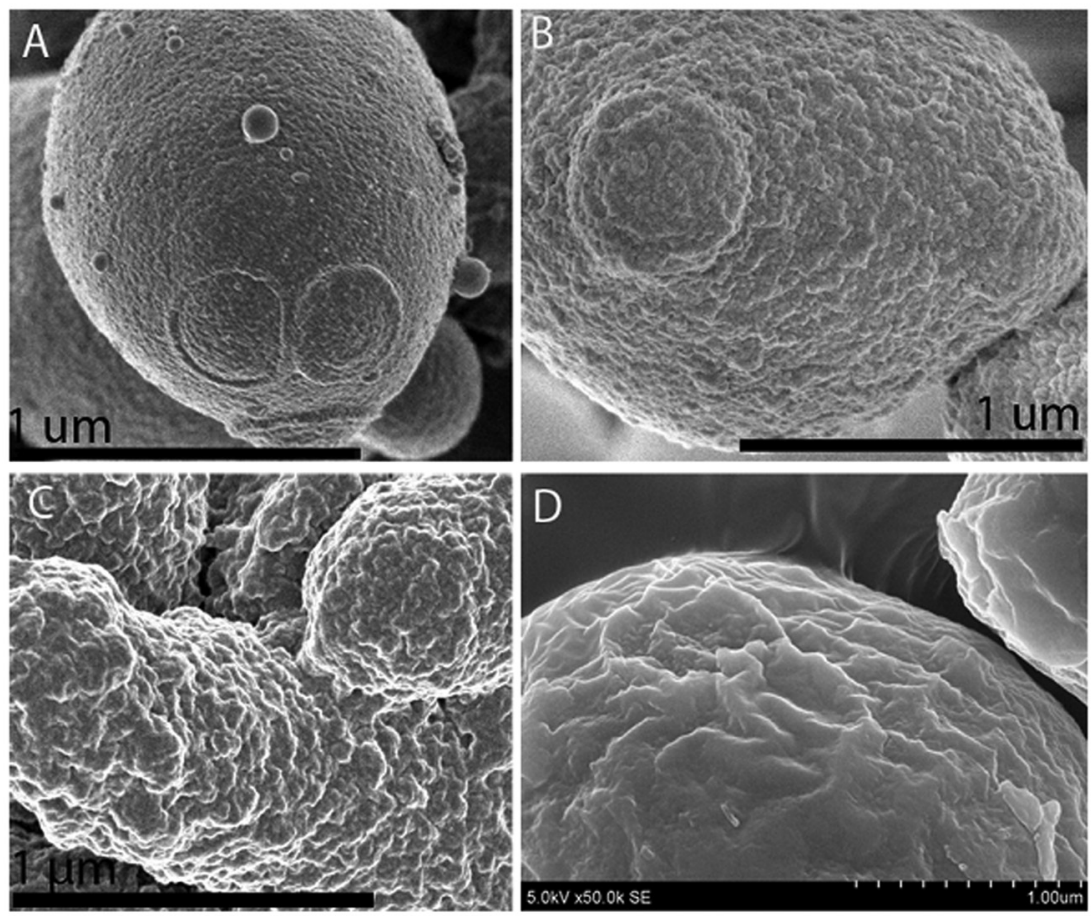

Figure 3 - Characterization of surface phenotype of C. albicans strains. The strains were grown in undiluted human serum at $30^{\circ} \mathrm{C}$ for $18 \mathrm{~h}$. Deletion of EFG1 (strain HLC 52; A) or/ and CPH1 (strain Can 16; B/ strain HLC54; C) results in roughness and warty phenotype. (D) Micrograph showing smooth phenotype of the C. albicans clinical strain 82 . Scanning electron micrographs.
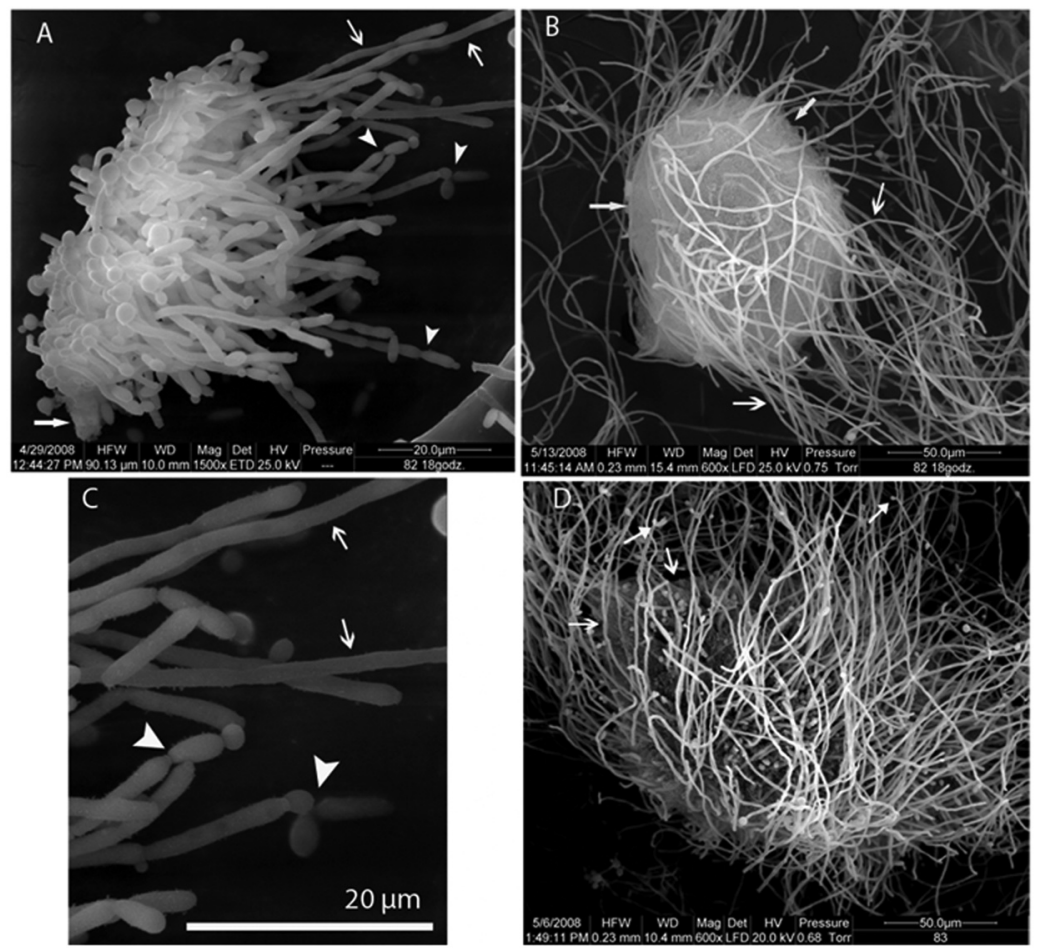

Figure 4 - Scanning electron micrographs of Candida albicans clinical strain's morphologies embedded in extracellular material. (A) Cells were grown in undiluted blood serum for $6 \mathrm{~h}$ at $37^{\circ} \mathrm{C}$. Clumps of morphological forms can be seen. Note the matrix material, indicated by an arrow. The tube-shaped blastoconidial cells (pseudohyphae) with fragile septal junction (arrowheads) were discerned. Note the long true hyphal morphologies (open arrows). (B) After $18 \mathrm{~h}$, extracellular material (arrows) formed under static conditions in plastic eppendorf vials. Yeast layer embedded in matrix material is not visible and upper mainly hyphal layer is indicated by open arrows. (C) The enlarged insert area of (A) shows the pseudohyphal morphologies in more details. Pseudohyphal cellular compartments are distinguished from those of hyphae (open arrows) by constrictions at the septal junction (arrows). (D) After $48 \mathrm{~h}$, note hyphal conglomerate development embedded in extracellular material (open arrows). True hyphal cells formed buds were noted (arrows). 

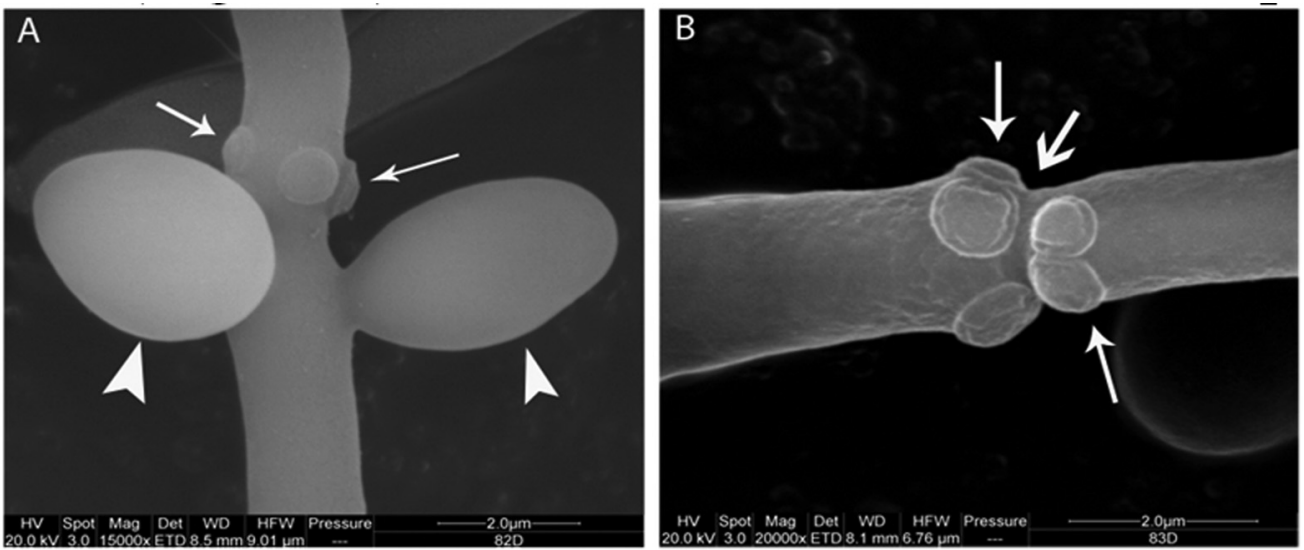

Figure 5 - The Candida albicans 82 incubated at $37^{\circ} \mathrm{C}$ for $48 \mathrm{~h}$ in undiluted human serum. Rings of truncated bud scars (arrows) located (A) at one side of the massive true hyphal septum and (B) at both sides of the septum. (B) Lack of constriction in the point of solid septum is seen (open arrow). Note new buds facing one another (arrowheads) located at the side of septum (A). True hyphal tops are the privileged budding areas. Scanning electron micrographs.

Table 2 - Morphology index (Mi) values for pleomorphic cells of Candida albicans clinical isolate grown for $18 \mathrm{~h}$ in undiluted human serum at $37^{\circ} \mathrm{C}$. Data estimated by measuring the cells documented by scanning electron micrographs.

\begin{tabular}{lccccc}
\hline \multirow{2}{*}{ Pleomorphic forms } & \multicolumn{3}{c}{ Morphology index (Mi) } & \multirow{2}{*}{ No. of cells examined } \\
\cline { 2 - 4 } & \multicolumn{2}{c}{ Range* } & Average & Standard deviation \\
\cline { 2 - 4 } & Minimum & Maximum & 1.11 & 0.1614 & 133 \\
Yeast & 1.0 & 1.5 & 1.93 & 0.2979 & 61 \\
Germ tube & 1.6 & 2.4 & 2.93 & 0.3401 & 47 \\
Pseudohyphae & 2.5 & 3.4 & 6.91 & 3.0761 & 215 \\
True hyphae & 3.5 & 20.4 & 4.143 & 3.4045 & 456 \\
Total & 1.0 & 20.4 & & \\
\hline
\end{tabular}

*Classification of pleomorphic forms based on Mi value: blastoconidia, 1.0-1.5; germ tube, 1.6-2.4; pseudohyphae, 2.5-3.4; true hyphae > 3.4 (Merson-Davies and Odds, 1989).

comparing with the wild type strain (Figure 4B, D). Contrariwise, both efg $1 \Delta /$ efg $1 \Delta$ and $c p h 1 \Delta / c p h 1 \Delta$ efg $1 \Delta / \operatorname{efg} 1 \Delta$ mutants failed to form true hyphae (Figure 6B-D) upon undiluted human serum stimulation. Thus, no true hyphae extended from germ tube emerged from yeasts were noted.

\section{Pseudohyphae}

In the case of the wild type strain 82 , pseudohyphae formed branched chains of elongated blastoconidial cells retaining constrictions at the septal junctions (Figure 4A, C). Fragile septal junctions are typical for pseudohyphal forms. Pseudohyphae were also wider than true hyphae forms. The average length-to-width ratios for pseudohyphal cells $(n=47)$ of wild type strain 82 were about 2.93 (Table 2). After $6 \mathrm{~h}$ of incubation in serum cells of the clinical isolate grew as a mix of pseudohyphae with a low proportion of true hyphal forms (Figure 4A, C). Null mutant $\operatorname{cph} 1 \Delta / \operatorname{cph} 1 \Delta$ and efg $1 \Delta / \operatorname{efg} 1 \Delta$ as well as double null mutant $\operatorname{cph} 1 \Delta / \operatorname{cph} 1 \Delta$ efg $1 \Delta /$ efg $1 \Delta$ formed elongated tube-like cells testified pseudohyphae (this due to elongated tube-shaped cells either singular or a few cells remaining attached as filaments as in Figure 6) after $18 \mathrm{~h}$-incubation in undiluted blood serum at $37^{\circ} \mathrm{C}$.

\section{Discussion}

Our data suggests that elongated tube-like buds of the null mutants $(\operatorname{cph} 1 \Delta / \operatorname{cph} 1 \Delta$, efg $1 \Delta / \operatorname{efg} 1 \Delta$ and efg $1 \Delta /$ efg $1 \Delta$ $\operatorname{cph} 1 \Delta / \operatorname{cph} 1 \Delta$ ) should be referred to as pseudohyphae (this is due to a constrictions at the fragile septal junction between tube-shaped cells remaining attached as in Figure 1D and Figure 6D, and the length-to-width ratios larger than 1.5). Because, a well-defined chains of pseudohyphal cells of mutant strains (Figure 1B-D) evidently consist of individuals with different modes of growth as well as ultrastructural shape and organization compared to typical blastoconidia of the wild type strain 82 (Figure 1A). Discrepancies in scar locations were also observed - even though the mutants exhibited predominantly, but not exclusively multiple polar budding (testified by numerous scars remaining after daughter cells had dropped out from the mother cell as in Figure 1C) but at the tips of the elongated 

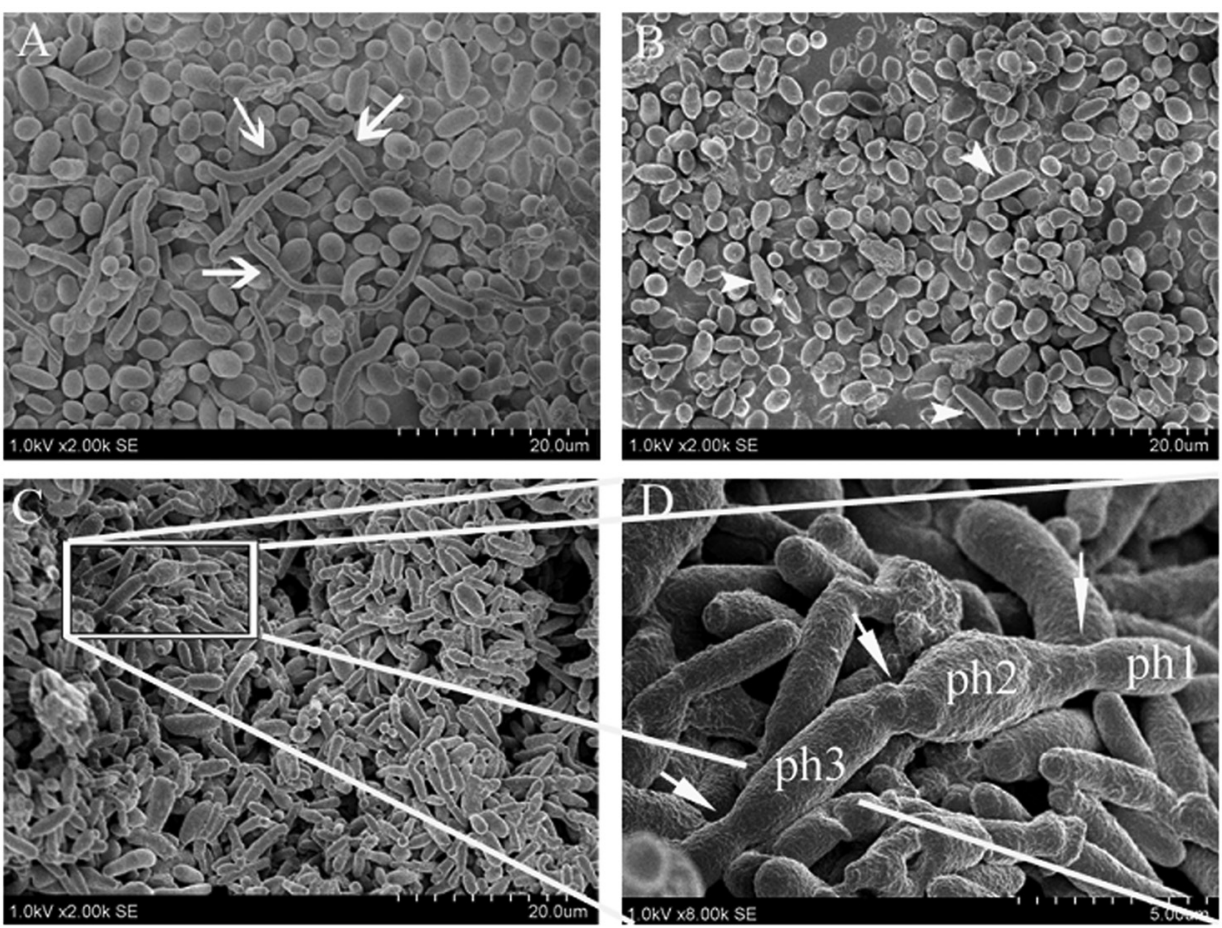

Figure 6 - Morphogenetic regulation by $\mathrm{Cph} 1$ and Efg1 under undiluted human serum influence for $18 \mathrm{~h}$ at $37^{\circ} \mathrm{C}$. (A) The strain $c p h 1 \Delta / c p h 1 \Delta$ (Can16) forms true hyphal morphologies under hypha-inducing conditions (open arrows). (B) The efg $1 \Delta /$ efg $1 \Delta$ null mutant (HLC52) morphologies were lock in elongated tube-shaped buds (arrowheads) resembling pseudohyphae. (C-D) The double mutant efg $1 \Delta /$ efg $1 \Delta \mathrm{cph} 1 \Delta / \mathrm{cph} 1 \Delta$ (HLC54) was able to form either singular or a few tube-like blastoconidial cells remaining attached as filaments. Note a chain of elongated tube-like blastoconidial cells (ph1, ph2, ph3)/ pseudohyphae with fragile septa (arrows). Scanning electron micrographs.

tube-shaped forms there was a centrally located single bud scar (mother-daughter cell junction) which distinguishes tube-like yeast cell/ pseudohyphal growth (Figure 1D). Contrariwise, the wild type strain exhibited rings of scars at the tips of oval shaped yeasts indicating budding phenotype of blastoconidial cells (either in YEPD or undiluted human serum, Figure 1A) rather than pseudohyphal phenotype typical for mutants (Figure 1B-D) following serum induction. Under these conditions, the clinical strain displayed smooth colonies (Figure 3D) in comparison to the homozygous mutants displayed wrinkled phenotype (Figure 3A-C and Figure 6A-D). Thus, we agree with others (Felk et al., 2002; Zhao et al., 2002) that Efg1 seems to play a major role in normal cell growth and hyphal morphogenesis in blood serum.

Incubation in human serum for $1 \mathrm{~h}$ (the wild type strain $\log$ phase of growth) resulted in blastoconidia unipolar germination combined with formation of cell aggregates (Figure 4A). Literature data (Gow et al., 2002; Argimon et al., 2007; Bauer and Wendland, 2007; Alonzo-Monge et al., 2010; Frade and Arthington-Skaggs, 2011; Giacometti et al., 2011; Staniszewska et al., 2011) describes that when serum is used as an inducer, cells readily aggregate (flocculate) and form clumps. In the study, SEM analysis also revealed that the wild type strain produced amorphous flocculent extracellular material, occurring in floating conglomerate of morphologies (Figure 4A, B, D) generated in serum at human body temperature. Our previous results (Staniszewska et al., 2011) justified by the phase-contrast microscope showed that incubation of C. albicans under the same growth conditions resulted in formation of floating (planktonic) Candida fungal ball-like conglomerates. In the central zone of the aggregate mainly spherical units undergoing transformation into true hyphal forms with large vacuoles were observed (Staniszewska et al., 2011). According to Steinberg (1998) the vacuoles have direct role in hyphal growth. Moreover, Alonso-Monge et al. (2010) and Giacometti et al. (2011) reported that serum induce the cell-surface glycoproteins i.e., Als $1 \mathrm{p}$ and Als3p (effectors of filamentation) that are important in early adhesion of planktonic morphologies of C. albicans. To further our knowledge of the hyphal morphogenesis induced by the presence of serum, we investigated Candida fungal-ball model under SEM (Figure 4A, B, D). We clearly established that hyphae (long, narrow, uninterrupted and sticking together) are essential elements for developing and providing the structural integrity of conglomerate, as the strains with mutations in genes governing morphogenesis are defective in their flocculation and conglomerateforming abilities (Figure 6A-D). The ability to grow as mycelia filaments is believed to be an important virulence trait in C. albicans (Pèrez et al., 2011) and hyphae are the most abundant cellular element which may be expected to play a role in bloodstream infections. Although, in the literature 
(Biswas et al., 2000; Braun and Johnson, 2000; Felk et al., 2002; Gow et al., 2002; Zhao et al., 2002; Kumamoto and Vinces, 2005; Müller and Melchinger, 2006; Argimon et al., 2007; Bauer and Wendland, 2007; Biswas et al., 2007; Barnett 2008; Kebaara et al., 2008; Kruppa 2009; AlonsoMonge et al., 2010; Ness et al., 2010; Noble et al., 2010) many examples of different media application to induce filamentous growth can be found, our investigation pointed out that undiluted human serum is the most effective in true hyphae and conglomerate formation (Figure 4A, B, D).

On the basis of our present microscopic analyses of the clinical strain's cells, it can be concluded that incubation in human serum at the temperature of $37^{\circ} \mathrm{C}$ for $18 \mathrm{~h}$ resulted in transformation of almost $100 \%$ of all observed cells to pure true hyphal forms (Figure 4A-D). Although, a certain number of mycelia forms were consistently observed after $48 \mathrm{~h}$ of induction at $37{ }^{\circ} \mathrm{C}$ under human serum influence, the hypha to bud interconversion occurred (Figure 5A; Staniszewska 2009). We expected that all morphological forms can be usually seen in human blood infections. Moreover, it is justified to assume that the wild type strain displayed altered morphologies related to nutritioncomponent changes occurred in the external environment. It may reflect the adaptation of $C$. albicans to different cues found within different niches of the host. As discussed previously (Lorentz et al., 2004; Yang et al., 2009; Lu et al., 2011), morphogenetic transition is crucial for C. albicans virulence. It is therefore possible that, the diversity in morphologies would provide them with the distinct advantage of rapid adaptation to cause candidiasis. Although blastoconidia are efficiently disseminated by bloodstream (Gow et al., 2002), true hyphal cells induced by human serum are more efficient in further stages of candidiasis (tissue penetration - invading deep organs and macrophage evasion; Dignani et al., 2003). Thus, the conglomerate of true hyphae due to enzymatically active apical tip (Fekete et al., 2007) may play a crucial role in blocking the main arteries (tamponade of right heart and pulmonary ventricles; Salfelder et al., 1990) and colonizing the microenvironment of the host (as ureter and renal fungal ball; Dignani et al., 2003; Nguyen et al., 2011).

In the paper we presented comparison between the $C$. albicans clinical isolate and strains lacking the transcription factors Cph1, Efg1 with regard to morphogenesis process induced under human serum influence. Although further analysis is required, we could infer several conclusions pertaining to ultrastructural morphology pattern of $C$. albicans pleomorphic forms. First, blastoconidial cells of the clinical bloodstream strain exhibited either a polarly or randomly located budding under blood serum influence. Second, morphogenesis-attenuated mutants demonstrated an abnormal morphological switching under human serum influence. The deletion of EFG1 in C. albicans resulted in a constitutive growth of elongated tube-shaped buds termed pseudohyphae in serum. Thus, Efg1 is required for se- rum-induced yeast-to-true hyphae transition. Third, our analysis along with the estimates of Müller and Melchinger (2006) and the discussion of our previously published results (Staniszewska et al., 2011) suggest that the two types of hyphae: pseudo- and true- differ in both structure (this due to fragile $v s$ solid septum), shape (wide and short $v s$ narrow and long), and Mi values (average values: 2.93 vs 6.91) and therefore their names cannot be used interchangeably as filamentous forms. According to Crampin et al. (2005), the apparent differences between morphotypes could be due to issue such as different growth. In general, polarisome components are required for hyphal growth, but not for yeast or pseudohyphal growth (Crampin et al., 2005). Fourth, if the ability to undergo the dimorphic transition were the major determinant of virulence, it would indicate that the wild type strain shows increased virulence in body fluids. The observation that mutants are defective in yeast-to-hypha transition support the thesis that these strains are attenuated for virulence in bloodstream infections. Fifth, to improve diagnosis of candidaemia and invasive candidiasis our data established morphological criteria for detection of fungal morphologies in human samples.

\section{Acknowledgments}

We are extremely grateful to many colleagues and all the individuals who were generous with their advice, and provided us with strains and reagents; Professor Hsiu-Jung Lo from National Health Research Institute in Zhunan (Taiwan) with the following strains: Can16, HLC52 and HLC54; Professor Danuta Dzierzanowska-Madalinska with the strain 82; Professor Bernhard Hube with the following strains: $\Delta$ sap 9 and $\Delta$ sap9-10; Gabriela SmolenskaSym, Ph.D with human serum. This work was supported by the NN 404113639 grant from the Ministry of Science and Higher Education in Poland.

\section{References}

Alonso-Monge R, Román E, Arana DM, Prieto D, Urrialde V, Nombela C, Pla J (2010) The Skol protein represses the yeast-to-hypha transition and regulates the oxidative stress response in Candida albicans. Fungal Genet Biol 47:587-601.

Argimon S, Wishart JA, Leng R, Macaskill S, Mavor A, Alexandris T, Nicholls S, Knight AW, Enjabert B, Walmsley R, Odds FC, Gow, NAR, Brown AJP (2007) Developmental Regulation in the Fungal Pathogen Candida albicans. Eukaryot Cell 6:682-692.

Barnett JA (2008) A history of research on yeasts 12: medical yeasts part I, Candida albicans. Yeast 25:385-417.

Bauer J, Wendland J (2007) Candida albicans Sfl1 Suppresses Flocculation and Filamentation. Eukaryot Cell 6:17361744.

Biswas SK, Yokoyama K, Nishimura, K, Miyaji M (2000) Effect of $\mathrm{pH}$, carbon source and $\mathrm{K}^{+}$on the $\mathrm{Na}^{+}$-inhibited germ tube formation of Candida albicans. ISHAM Med Mycol 38:363-369. 
Biswas SK, Van Dijck P, Datta A (2007) Environmental Sensing and Signal Transduction Pathways Regulating Morphogenic Determinants of Candida albicans. Microbiol Mol Biol Rev 71:348-376.

Braun BR, Johnson AD (2000) TUP1, CPH1 and EFG1 make independent contributions to filamentation in Candida albicans. Genetics 155:57-67.

Chung SC, Kim TI, Ahn CH, Shin J, Oh KB (2010) Candida albicans PHO81 is required for the inhibition of hyphal development by farnesoic acid. FEBS Lett 584:4639-4645.

Crampin H, Finley K, Gerami-Nejad M, Court H, Gale Ch, Berman J, Sudbery P (2005) Candida albicans hyphae a Spiztenkörper that is distinct from the polarisome found in yeast and pseudohyphae. J Cell Sci 118:2935-2947.

Cullen PJ, Sprague GF (2000) Glucose depletion causes haploid invasive growth in yeast. PNAS 97:13619-13624.

Dignani MC, Solomkin JS, Anaissie EJ (2003) Candida. In: Anaissie, E.J.; McGinnis, M.R.; Pfaller, M.A. (eds) Clinical Mycology. Churchill Livingstone, Philadelphia, pp 195239.

Fekete A, Ermi T, Gyetvai A, Gazdag Z, Pesti M, Varga Z, Balla J, Cserháti C, Emödy L, Gergely L, Pócsi I (2007) Development of oxidative stress tolerance resulted in reduced ability to undergo morphologic transitions and decreased pathogoenicity in a $t$-butylhydroperoxide-tolerant mutant of Candida albicans. FEMS Yeast Res 7:834-847.

Felk A, Kretschmar M, Albrecht A, Schaller M, Beinhauer S, Nichterlein T, Sanglard D, Korting HC, Schäfer W, Hube B (2002) Candida albicans hyphal formation and expression of the Efg1-regulated proteinases Sap4 to Sap6 are required for the invasion of parenchymal organs. Infect Immun 70:3689-3700.

Frade PF, Arthington-Skaggs BA (2011) Effect of serum and surface characteristics on Candida albicans biofilm formation. Mycoses 54:e154-e162.

Giacometti R, Kronberg F, Biondi RM, Passeron S (2011) Candida albicans TpkIp and Tpk $2 p$ isoforms differentially regulate pseudohyphal development, biofilm structure, cell aggregation and adhesins expression. Yeast doi: 10.1002/yea.1839.

Gow NAR, Brown AJP, Odds FC (2002) Fungal morphogenesis and host invasion. Curr Opin Microbiol 5:366-371.

Kebaara BW, Langford ML, Navarathna DHML, Dumitru R, Nickerson KW, Atkin AL (2008) Candida albicans TUP1 is involved in farnesol-mediated inhibition of filamentousgrowth induction. Eukaryot Cell 7:980-987.

Kruppa M (2009) Quorum sensing and Candida albicans. Mycoses 52:1-10.

Kumamoto CA, Vinces MD (2005) Contributions of hyphae and hypha-co-regulated genes to Candida albicans virulence. Cell Microbiol 7:1546-1554.

Lo HJ, Köhler JR, DiDomenico B, Loebenberg D, Cacciapuoti A, Fink GR (1997) Nonfilamentous C. albicans mutants are avirulent. Cell 90:939-949.

Lorenz MC, Bender JA, Fink GR (2004) Transcriptional response of Candida albicans upon internalization by macrophages. Eukaryot Cell 3:1076-1087.

Lu Y, Su C, Wang A, Liu H (2011) Hyphal development in Candida albicans requires two temporally linked changes in promoter chromatin for initiation and maintenance. PLoS Biol 9:e1001105.

Merson-Davies LA, Odds F (1989) A morphology index of characterization of cell shape in Candida albicans. J Gen Microbiol 135:3143-3152.

Müller J, Melchinger W (2006) Ultrastructural characters defining the terms 'yeast cell', 'pseudomycelium' and 'true mycelium' in Candida albicans. Mycoses 49:24-30.

Ness F, Prouzet-Mauleon V, Vieillemard A, Lefebvre F, Noel T, Crouzet M, Doignon F, Thoraval D (2010) The Candida albicans $\mathrm{Rgd1}$ is a RhoGAP protein involved in the control of filamentous growth. Fungal Genet Biol 47:1001-1011.

Nguyen KA, Zmeter G, Claris O, Kassai B (2011) Epidemiology of invasive Candida infection in a neonatal intensive care unit in France. Acta Paediatr doi: 10.1111/j.1651-2227.2011.02514.x

Noble SM, French S, Kohn LA, Chen V, Johnson AD (2010) Systematic Screens of Candida albicans homozygous deletion library decouple morphogenetic switching and pathogenicity. Nat Genet 42:590-598.

Oliviera MT, Specian AFL, Andrade CGTJ, França EJG, Furlaneto-Maia L, Furlaneto MC (2010) Interaction of Candida parapsilosis isolates with human hair and nail surfaces revealed by scanning electron microscopy analysis. Micron 41:604-608.

Pèrez A, Ramage G, Blanes R, Murgui A, Casanova M, Martínez JP (2011) Some biological features of Candida albicans mutants for genes coding fungal proteins containing the CFEM domain. FEMS Yeast Res 11:273-284.

Salfelder K, de Liscano TR, Sauertaig E (1990) Atlas of Fungal Pathology. Kluwer Academic Publishing, Dordrecht, Boston, London.

Schild L, Heyken A, de Groot PWJ, Hiller E, Mock M, de Koste C, Horn U, Rupp S, Hube B (2011) Proteolytic cleavage of covalently linked cell wall proteins by Candida albicans Sap9 and Sap10. Eukaryot Cell 10:98-109.

Sudbery P, Gow N, Berman J (2004) The distinct morphogenic states of Candida albicans. Trends Microbiol 12:317-324.

Staniszewska M (2009) Search for Candida albicans virulence factors. Warsaw, Poland, 146 p. (Ph.D. Thesis. National Institute of Public Health - National Institute of Hygiene. NIZP-PZH).

Staniszewska M, Bondaryk M, Kurzatkowski W (2011) Morphotypes of Candida albicans. Phase-contrast microscopy. Mikol Lek 18:5-10.

Staniszewska M, Bondaryk M, Siennicka K, Kurzatkowski W (2012) Ultrastructure of Candida albicans pleomorphic forms: Phase-contrast microscopy, scanning and transmission electron microscopy. Pol J Microbiol 61:129-135.

Steinberg G (1998) Organelle transport and molecular motors in fungi. Fungal Genet Biol 24:161-177.

Yang YL, Wang CW, Chen CT, Wan MH, Hsiao CF, Lo HJ (2009) Non-lethal Candida albicans cph1/cph1 efgl/efgl mutant partially protects mice from systemic infections by lethal-type cells. Mycol Res 113:388-390.

Zhao R, Lockhart SR, Daniels K, Soll DR (2002) Roles of TUP1 in switching, phase maintenance, and phase-specific gene expression in Candida albicans. Eukaryot Cell 1:353-365.

All the content of the journal, except where otherwise noted, is licensed under a Creative Commons License CC BY-NC. 